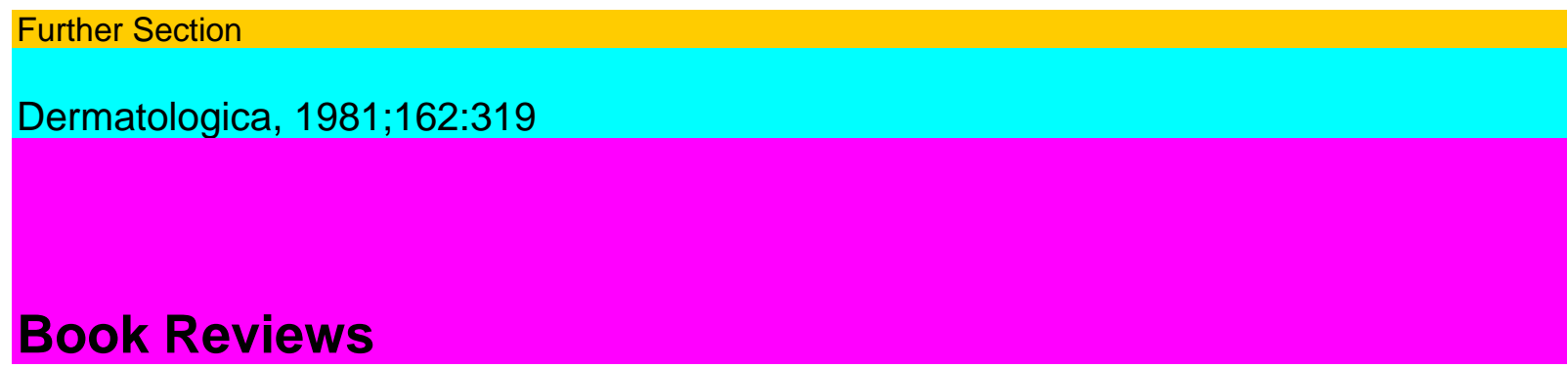

\title{
M. Allen
}

Skin Diseases in Vietnam 1965-1972

vol. 1

US-Government Printing Office, Washington, D.C. 1980. 185 pp.; US \$ 8.25

Stock No. 008-023-00051-4

In diesem Büchlein werden die Erfahrungen dargelegt, die die amerikanischen Militärdermatologen im Vietnamkrieg gemacht haben. In einem ersten Teil wird der Aufbau eines dermatologischen Sanitätsdienstes dargestellt, der praktisch von Null anfangen musste, da in früheren Kriegen der Militärdermatologie kaum Beachtung geschenkt wurde. In Vietnam hingegen, im sumpfigen Gebiet und im tropischen Klima, erkrankten sehr viele Soldaten an Hautkrankheiten, die zum Teil eine längere Dienstunfähigkeit bedingten. In einem zweiten Teil werden diese Dermatosen beschrieben. Die wichtigsten waren Infekte mit Pilzen und Bakterien. Trichophytoninfektionen wurden in der Regel durch Ratten übertragen. Eine spezifische Krankheit war die Nässeschädigung der Füsse, die durch den oft tagelangen Aufenthalt in überschwemmten Gebieten und in Reisfeldern verursacht wurde und häufig eine Hospitalisierung notwendig machte. Die eigentlichen Tropenkrankheiten waren dagegen sehr selten. In einem letzten Abschnitt finden sich Überlegungen über prophylaktische und therapeutische Massnahmen. R. Schuppli, Basel K. Zürcher and A. Krebs Hautnebenwirkungen interner Arzneimittel Cutaneous Side Effects of Systemic Drugs

S. Karger, Basel 1981, xii + 370 pp.; SFr. 123-ISBN 3-8055-0019-X

This book assuredly represents the most complete one realized on the cutaneous side effects of systemic drugs. It may be used for two purposes: when looking for the cutaneous side effect of a particular drug or when looking for the drugs which may cause particular cutaneous symptoms. The book is divided into five parts: (I) analgesics, antipyretics, antiarthritics; (II) antiinfectious drugs; (III) drugs affecting autonomic and vegetative func tions and organs; (IV) drugs affecting the central nervous system, and (V) cytostatic hor mones and miscellanies. The references are particularly numerous; part II, e.g., comprises more than 800 . This represents a huge work and the volume must heartily be recommended to all dermatologists. G. Achten, Brussels 